\title{
Pola Sidik Jari Tangan dan Ciri Fisik Penderita Sindrom Down di Sekolah Luar Biasa (SLB) Kota Jember
}

\author{
(Fingerprint Patterns and Physical Characteristics of Down Syndrome in Jember Disability Schools)
}

\author{
Indah Yunitasari, Mahriani, Rike Oktarianti \\ Jurusan Biologi, Fakultas Matematika dan Ilmu Pengetahuan Alam, Universitas Jember \\ Jln. Kalimantan 37, Jember 68121 \\ E-mail: rike.fmipa@unej.ac.id
}

\begin{abstract}
Abstrak
Sindrom down merupakan kelainan akibat penambahan jumlah kromosom tubuh nomor 21 sehingga mempengaruhi ciri fisik, pola dan jumlah sulur ujung jari tangan. Tujuan dari penelitian ini untuk mengetahui ciri fisik, pola sidik jari dan jumlah sulur penderita sindrom down. Pengambilan sampel dilakukan di SLB Kota Jember, data ciri fisik didokumentasikan, dideskripsikan dan dianalisis dengan Uji Wilcoxon untuk mengetahui signifikansi perbedaan dengan orang normal. Pola dan jumlah sulur dilakukan perekaman dengan menempelkan ujung jari pada bantalan tinta selanjutnya ditempelkan pada kertas HVS. Selanjutnya ditentukan pola sidik jari dan dihitung jumlah sulurnya. Jumlah sulur selanjutnya diuji Independent Sampel T-Test untuk mengetahui perbedaan dengan orang normal. Hasil penelitian menunjukkan bahwa ciri fisik siswa SLB Kota Jember mempunyai perbedaan yang signifikan dengan orang normal meliputi hidung pesek, mulut kecil dan cenderung membuka, jari tangan pendek. Ketiga parameter tersebut pada Uji Wilcoxon menunjukkan perbedaan yang nyata dengan orang normal. Karakter lain yaitu mata sipit dan membujur keatas serta terdapat lipatan mata (epikantus), ujung lidah yang melebar, telapak tangan siswa umumnya mempunyai garis simian, jari kelingking yang bengkok, serta pada jari kaki pertama dan kedua mempunyai jarak lebar. Pola sidik jari siswa adalah loop ulnar $(84,17 \%)$ dengan jumlah sulur rata-rata 145,59 sulur, lebih banyak dari orang normal. Hasil uji Independent Sampel T-Test menunjukkan perbedaan yang signifikan antara siswa penderi sindrom down dengan orang normal.
\end{abstract}

Kata Kunci: pola sidik jari, sindrom down, SLB.

\section{Abstract}

Down syndrome is an abnormality due to the addition number of chromosomes $21^{\text {st }}$ that affects the physical characteristics, patterns and ridges count of the fingertips. The purpose of this study was to determine the physical characteristics, fingerprint patterns and number of fingerprint ridges. Sampling carried out at the disability school in Jember. Physical characteristics data were documented, described and analyzed by the Wilcoxon Test to determine the significance of differences with normal people. The fingerprint pattern and amount of ridges recorded by attaching the fingertips to the ink pads then affixed to the HVS paper. The fingerprint pattern was determined and the number of ridges was calculated. The number of ridges was tested by the Independent Sample T-Test to find out the difference between down syndrome's student and normal people. The results showed that the physical characteristics of down syndrome students of the Jember disability schools had significant differences with normal people including pug nose, small mouth and tend to open, short fingers. The three parameters in the Wilcoxon Test revealed a significant difference with normal people. Other characters are narrow eyes and longitudinal upward and there are eye folds (epicantus), widened tip of the tongue, students' palms generally have simian lines, bent little fingers, and on the first and second toes have wide distances. The down syndrome student's fingerprint pattern was the ulnar loop (84.17\%) with an average number of ridges was 145.59 that higher than normal people. The results of the Independent T-Test sample showed a significant difference between Down Syndrome students and normal people.

Keywords: fingerprint patterns, down syndrome, SLB.

\section{PENDAHULUAN}

Setiap individu mempunyai identitas diri berupa sidik jari yang terbentuk sejak janin dalam kandungan berusia 13 minggu sampai 24 minggu (Akingbade et al., 2014). Sidik jari yang terbentuk akan tetap dipertahankan seumur hidup dan mempunyai perbedaan pada setiap individu (Purbasari dan Sumadji, 2017). Perbedaan ini dapat dilihat dari pola dan jumlah sulur ujung jari yang dapat digunakan untuk mengungkap kelainan seseorang (Suftini, 2007). Sidik jari pada manusia mempuyai tiga pola utama yaitu arch, loop dan whorl (Sufini, 2007; Mundijo, 2016; Purbasari 2017).
Pola arch merupakan pola paling sederhana yang dapat ditemukan di ujung jari. Pola ini membentuk kurva yang cekung secara proksimal dan membentuk garis sejajar yang melengkung menyerupai busur serta tidak mempunyai triradius. Pola arch dibagi menjadi tented arch dan plain arch (Ainur et al., 2009). Tented arch terbentuk dari garis lengkung yang bertemu pada suatu titik, sedangkan plain arch membentuk lengkungan dari satu sisi ke sisi lain yang tidak simetris (Ainur et al., 2009; Ramani et al., 2011). Pola loop terbagi atas loop radial dan loop ulnar.Pola loop membentuk garis lengkung seperti kait yang berulang yang mempunyai satu triradius, apabila lengkungan tersebut 
terbuka di sisi ulnar disebut loop ulnar dan apabila terbuka pada sisi radial disebut loop radial (Ainur et al., 2009; Purbasari, 2017). Pola whorl merupakan bentuk garis yang melingkar dan mempunyai titik triradius lebih dari satu. Pola whorl mempunyai empat macam pola yaitu plain whorl, double loop whorl, accidental dan central pocket loop (Ainur et al., 2009; Ramani et al., 2011; Mridula, 2014; Kanbar 2016; Dias et al., 2018). Pola plain whorl mempunyai garis pusar paling sedikit satu garis yang melingkar dan mempunyai titik triradius lebih dari satu. Garis pusar tersebut mempunyai paling sedikit satu garis pusar yang saling bersinggungan. Pola central pocket loop mempunyai garis pusar paling sedikit satu yang melingkar dan mempunyai titik triradius lebih dari satu. Garis pusar tersebut tidak saling bersinggungan. Pola double loop whorl merupakan pola yang tersusun dari dua bentuk loop yang terpisah berlawanan dengan dua titik triradius sehingga pola double loop whorl membentuk pola seperti huruf "S". Accidental whorl merupakan gabungan antara dua pola atau lebih yang dilengkapi dengan titik triradius lebih dari dua (Mridula, 2014). Sidik jari digunakan dalam bidang kepolisian sebagai alat identifikasi dan bukti forensik (Wati et al. 2016), selain itu juga juga digunakan dalam bidang kedokteran untuk mendiagnosis berbagai kelainan klinis (Amadino et al., 2014).

Kelainan yang dapat diungkap melalui sidik jari dapat disebabkan oleh mutasi gen atau aberasi kromosom (Kosim et al., 2012). Aberasi kromosom dapat mengakibatkan abnormalitas struktur dan jumlah kromosom. Adanya abnormalitas jumlah kromosom dapat mengakibatkan kelainan yaitu sindrom turner, sindrom down, sindrom klinefelter, sindrom patau dan sindrom Edward (Jenkins, 1990; Ahmad et al., 2010; Laksono et al., 2011).Sindrom down merupakan kelainan akibat adanya penambahan jumlah kromosom tubuh nomor 21 (Grieco et al., 2015). Adanya kelebihan kromosom ini dapat mempengaruhi ciri fisik, pola sidik jari dan jumlah sulur jari tangan. Ciri fisik penderita sindrom down berbeda dengan orang normal dan mempunyai kemiripan satu dengan yang lain. Hal ini dapat dilihat dari karakter wajah yang meliputi; mata yang sipit dan mempunyai epikantus, hidung pesek, mulut kecil ujung lidah lebar (Sureshbabu, et al., 2011; Kosim et al., 2012; Suryo, 2016; Purbasari dan Sumadji, 2017). Postur tubuh lebih pendek, adanya garis simian pada telapak tangan, kondisi jari tangan pendek dan jari kelingking bengkok serta jarak jari kaki I dan II mempunyai jarak lebih lebar (Thomas dan Harvey, 1984; Purbasari dan Sumadji, 2017). Penambahan kromosom juga dapat mempengaruhi pola sidik jari dan jumlah sulur ujung jari tangan. Menurut Rosida dan Panghiyang (2006) pada penderita sindrom down mempunyai pola loop ulnar dengan presentase $75,85 \%$ dengan Jumlah sulur ujung jari tangan 158 sulur.

Diagnosa awal terhadap siswa di SLB (Sekolah Luar Biasa) Kota Jember untuk membandingkan penderita sindrom down dengan siswa lain hanya dilihat pada ciri fisik tersebut diatas. Selanjutnya untuk memastikan siswa tersebut sebagai penderita sindrom down perlu dilakukan pemeriksaan lain yaitu menggunakan sidik jari. Adanya guratan pada ujung jari dapat digunakan untuk mengetahui pola dan jumlah sulur jari tangan sebagai pendukung ciri fisik. Selain itu dilakukan penelusuran keluarga untuk mengetahui latar belakang siswa. Penelitian ini bertujuan untuk mengetahui ciri fisik pola sidik jari, jumlah total sulur ujung jari tangan serta latar belakang siswa yang diduga penderita sindrom down.

\section{METODE PENELITIAN}

\section{Tempat dan Waktu Penelitian}

Pengambilan sampel penelitian ini dilaksanakan di SLB Kota Jember yang meliputi SLB Negeri Jember, SLB Negeri Branjangan, SLB YPAC Kaliwate, SLB Star Kids dan SLB TPA C Sumbersari. Responden pada penelitian ini terdiri atas 8 siswa laki-laki dan 14 siswa perempuan dengan orang normal sebagai pembanding 10 orang. Penelitian ini selanjutnya data dianalisis di Laboratorium Zoologi Jurusan Biologi Fakultas Matematika dan Ilmu Pengetahuan Alam pada bulan April sampai Juni 2019.

\section{Pemeriksaan Ciri Fisik, Pola dan Jumlah Sulur Jari Tangan Anak yang Diduga Penderita Sindrom Down}

Pemeriksaan ini dilakukan dengan melihat keadaan; mata (sipit, besar), (jarak kedua mata berjauhan, berdekatan), ada tidaknya lipatan mata/ epikantus; postur tubuh (tinggi badan); telapak tangan ada/tidaknya garis simian; jari kelingking (lurus, membengkok); jari kaki posisi jari I dan II (berjauhan, berdekatan); hidung (pesek dan melebar, mancung); mulut (lebar, kecil), (menutup, selalu membuka); jari tangan (pendek, panjang. Ciri fisik tersebut difoto, dideskripsikan dan pada parameter hidung, hidung, mulut dan jari dilakukan Uji Wilcoxon untuk mengetahui perbedaan antara orang normal dan siswa yang diduga sindrom down.

Perekaman sidik jari dilakukan dengan menempelkan kedua tangan pada bantalan tinta kemudian ditempel pada kertas HVS. Hasil rekaman tersebut diamati dan ditentukan pola sidik jari (loop, arch dan whorl). Selanjutnya dilakukan perhitungan jumlah total sulur ujung jari menggunakan bantuan kaca pembesar. Perhitungan ini dilakukan dengan menentukan titik triradius dan titik pusat, kemudian ditarik garis pada kedua titik tersebut. Perhitungan jumlah sulur dimulai pada garis setelah titik triradius sampai garis sebelum titik pusat. Pola whorl yang mempunyai dua titik triradius dilakukan perhitungan pada kedua sisi dan diambil pada sisi yang mempunyai sulur lebih banyak, sedangkan pada pola arch yang tidak mempunyai titip pusat maka jumlah sulurnya adalah 0 . Jumlah total sulur (Total Ridge Count) diperoleh dengan menjumlahkan perhitungan sulur dari ke-10 jari tangan (Altman, 2005; Siburian, 2010). Jumlah sulur yang didapat selanjutnya dilakukan uji Independent Sampel T-Test untuk mengetahui ada tidaknya perbedaan antara siswa yang diduga sindrom down dengan orang normal.

\section{HASIL DAN PEMBAHASAN}

\section{Identifikasi ciri fisik penderita sindrom down}

Hasil pemeriksaan ciri fisik pada siswa SLB Kota Jember yang diduga penderita sindrom down berjumlah 22 siswa yang terdiri atas 8 siswa laki-laki dan 14 siswa perempuan. Ciri fisik yang diamati meliputi mata, hidung, mulut, ujung lidah dapat dilihat pada Gambar 4.1. 


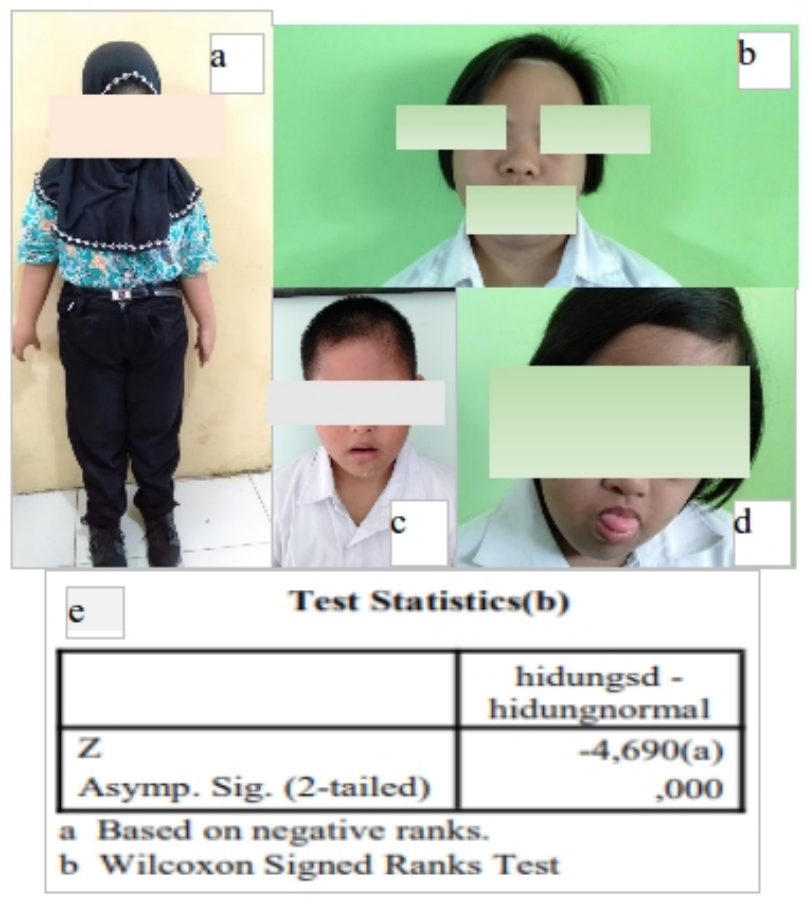

(a) Postur tubuh; (b) hidung; ( c) mulut; (d) ujung lidah, (e) Uji Wilcoxon

Gambar 4.1 Ciri fisik siswa yang diduga penderita sindrom down

Ciri fisik siswa mempunyai mata dengan keadaan sipit dan terdapat lipatan mata (epikantus) pada sudut mata. Menurut Sureshbabu et al., (2011); Saraydemir, (2012); dan Gottimukkula et al., (2017) penderita sindrom down mempunyai mata yang sipit naik ke atas dan di sudut mata terdapat lipatan (epicantus). Ujung lidah siswa mempunyai ujung yang tumpul Gambar 4.1 (d). Menurut Saraydemir (2012) lidah pada penderita sindrom down lebar dan menonjol keluar. Postur tubuh siswa mempunyai tinggi badan terendah adalah $109 \mathrm{~cm}$ dan tertinggi $150 \mathrm{~cm}$ dengan rata-rata $132 \mathrm{~cm}$ Gambar 4.1 (a). Menurut Myrelid (2002) penderita sindrom down mempunyai tinggi maksimal pada usia maksimal 18 tahun yaitu pada laki-laki $161,5 \mathrm{~cm}$ dan wanita 147, $5 \mathrm{~cm}$. Hidung siswa lebih lebar dan pesek Gambar 4.1 (b), serta mulut yang berukuran kecil dan cenderung membuka Gambar 4.1(c). Berdasarkan hasil uji Wilcoxon pada parameter hidung, mulut dan jari tangan yang dibandingkan dengan orang normal pada penelitian ini mempunyai nilai signifikansi $p=0.00<0,05$ Gambar 4.1 (e). Hal ini menunjukkan terdapat perbedaan yang nyata antara orang normal dengan siswa yang diduga sindrom down. Umumnya orang normal mempunyai hidung yang tidak membesar dari pangkal dengan mulut yang berukuran kecil. Hidung pada penderita sindrom down umumnya pesek dan melebar dengan mulut yang kecil (Sureshbabu et al., 2011; Saraydemir 2012; dan Gottimukkula et al., 2017).

Karakter lain yang diamati pada siswa yaitu pada telapak tangan, dan jari kaki seperti pada Gambar 4.2. Telapak tangan siswa terdapat garis simian pada telapak tangan kanan (ditunjuk anak panah). Menurut Sanilkumar (2014) adanya garis simian pada telapak tangan dapat membantu diagnosa penyakit terkait aberasi kromosom, namun pada manusia normal memungkinkan ditemukannya garis simian dalam frekuensi kecil. Keadaan jari tangan siswa pendek disertai dengan jari kelingking yang bengkok. Menurut Kazemi et al., (2016) pada jari kelingking penderita sindrom down terjadi pemendekan falang tengah yang mengakibatkan pembengkokan pada ujung jari. Kondisi jari kaki siswa pada jari I (ibu jari) dan ke II mempunyai jarak. Adanya perubahan jumlah kromosom dapat mengakibatkan perbedaan ciri fisik (Kosim et al., 2012).

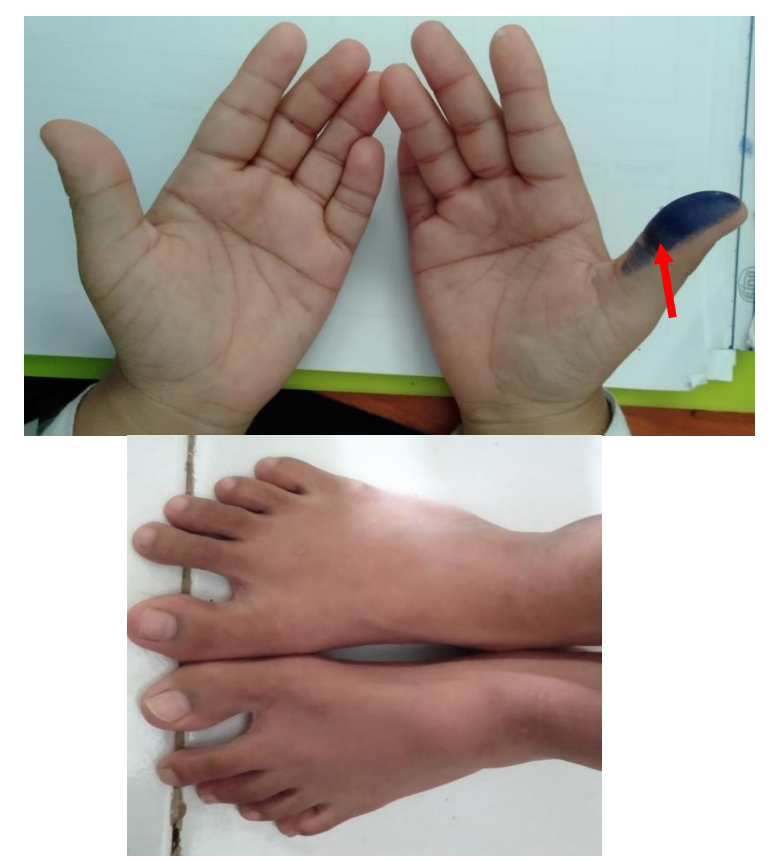

Gambar 4.2 Kondisi tangan dan kaki siswa yang diduga penderita sindrom down

Pola sidik jari dan jumlah sulur ujung jari tangan siswa

Hasil penelitian terhadap pola sidik jari pada siswa yang diduga sindrom down di SLB Kota Jember mempunyai presentase pola sidik jari yang berbeda-beda, seperti pada Gambar 4.3. Frekuensi pola loop ulnar mempunyai presentase paling tinggi yaitu $84.17 \%$ dan presentase paling rendah adalah tipe pola arch yaitu $0.22 \%$. Hasil penelitian ini sesui dengan penelitian Rosida dan Panghiyangani (2006) bahwa pada penderita sindrom down mempunyai tipe pola sidik jari loop ulnar dengan presentase tertinggi yaitu $75,83 \%$.

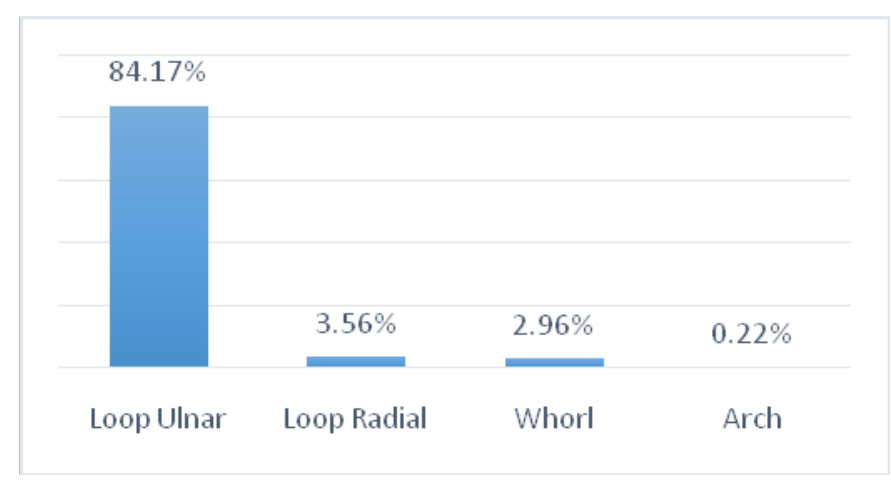

Gambar 4.3 Diagram frekuensi pola sidik jari siswa yang diduga sindrom down 
Pola loop ulnar merupakan pola yangmembentuk garis lengkung seperti kait yang berulang dan terbuka di sisi ulnar. Karakter pola loop ulnar adalah mempunyai titik triradius (delta) berjumlah satu seperti pada Gambar 4.4. Titik triradius merupakan titik awal dalam perhitungan jumlah sulur menuju ke pusat (core) (Ainur et al., 2009; Purbasari, 2017).

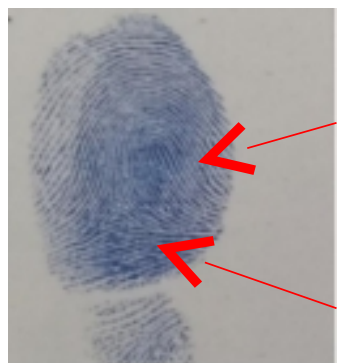

\section{Pusat \\ (core \\ Titik \\ Triradius \\ (delsa)}

Gambar 4.4 Pola loop ulnar ujung jari tangan siswa yang diduga sindrom down

Hasil perhitungan jumlah sulur ujung jari tangan pada siswa yang diduga penderita sindrom down mempunyai rata-rata 145,59 sulur (Tabel 4.1). Rata-rata jumlah sulur tersebut terdiri atas 75 sulur pada tangan kanan dan 70,59 sulur pada tangan kiri. Hasil uji T-test pada jumlah sulur siswa dengan orang normal didapatkan nilai signifikansi $\mathrm{p}=$ $0,01<0,05$ menunjukkan terdapat perbedaan signifikan antara siswa yang diduga sindrom down dengan orang normal. Bahwa hasil penelitian yang terkait jumlah sulur ujung jari tangan sesuai dengan penelitian Irawan (2010) yang menyatakan bahwa rata-rata jumlah sulur ujung jari pada penderita sindrom down lebih tinggi dibandingkan dengan orang normal yaitu 144,1 sulur pada penderita sindrom down dan 100,5 sulur pada orang normal. Rosida dan Panghiyangani (2006) juga menyatakan bahwa jumlah sulur ujung jari tangan penderita sindrom down lebih besar dari orang normal yaitu sebesar 158 sulur.

Tabel 4.1 Jumlah sulur ujung jari tangan siswa yang diduga sindrom down

\begin{tabular}{cccc}
\hline & Kanan & Kiri & Total \\
\hline Total & 1650 & 1553 & 3203 \\
Rata-rata & 75,00 & 70.59 & 145,59
\end{tabular}

Penelusuran Latar Belakang Keluarga Siswa yang Diduga Penderita Sindrom Down

Berdasarkan hasil penelusuran latar belakang keluarga siswa dalam hal ini delapan responden.Empat diantaranya menyatakan usia ibu ketika mengandung anak (siswa sampel) pada usia 35-47 tahun, sedangkan empat lainnya pada usia 25-30 tahun. Penyebab tebesar terjadinya sindrom down adalah nondisjunction pada meiosis I dan II dalam pembelahan sel telur maupun sel sperma(Ahmad, 2010) . Menurut Oliver (2008) persentase terjadinya nondisjunction lebih tinggi terjadi pada sel telur dibandingkan dengan sperma sehingga nondisjunction dapat dipengaruhi oleh usia ibu. Semakin tua usia ibu maka semakin besar terjadinya nondisjunction dan semakin besar pula melahirkan anak sindrom down.Berdasarkan Rahma dan
Indrawati (2017) resiko melahirkan anak sindrom down pada usia kurang dari 30 tahun adalah 1 dari 1000 kelahiran bayi. Usia ibu antara 30-34 tahun kelahiran anak penderita sindrom down akan meningkat menjadi 1 dari 750 kelahiran. Usia ibu diatas 35 tahun dapat mencapai 1 dari 100 kelahiran bayi. Menurut Nurwahidah (2015) bertambahnya usia ibu ketika mengandung anak akan menyebabkan penuaan materi genetik yang memungkinkan terjadinya kesalahan dalam pembelahan sel, selain itu penyebab terlahirnya anak sindrom down selain dari penuaan materi genetik juga dapat disebabkan oleh adanya pengaruh obat saat kehamilan.

\section{KESIMPULAN}

Berdasarkan hasil penelitian terhadap 22 siswa SLB Kota Jember yang diduga sindrom down mempunyai ciri fisik mataa sipit, membujur keatas ada lipatan mata (epikantus), ujung lidah melebar, telapak tangan siswa mempunyai garis simian, jari kelingking bengkok, jari kaki I (ibu jari) dan II mempunyai jarak lebih lebar. Hasil terhadap ciri fisik hidung, mulut dan jari pada uji wilcoxon menunjukkan terdapat perbedaan yang signifikan dengan orang normal. Pola sidik jari pada siswa adalah loop ulnar $(84,17 \%)$ dengan jumlah sulur rata-rata pada ujung jari tangan 145.59. Hasil uji T-Test menunjukkan terdapat perbedaan yang signifikan antara orang normal dan siswa yang diduga sindrom down.

\section{DAFTAR PUSTAKA}

[1] Ahmad, M., Silvera-Redondo, dan M. H. Rodriguez. 2010. Nondisjunction and Chromosomal Anomalies. Salud Uninorte, Barranquilla, 26(1):117-133.

[2] Ainur, A., J. Hastuti, dan Z. S. Nugraha. 2009. Pola Sidik Jari Anak-anak Sindrom Down di SLB Bakhti Kencana dan Anak-anak Normal di SLB Budi Mulia Dua Yogyakarta. Jurnal Kedokteran dan Kesehatan Indonesia.

[3] Akingbade, A. M., L. C. Saalu, G. G. Akunna, L. E. Anderson, dan F. S. Olusolade. 2014. Finger and Palmar Dermatoglyphic Study Among the Yorubas in Jos, Nigeria. Annals of Bioanthrojournal, 2(2): 49-53.

[4] Altman, N. 2005. Palmistry: The Universal Guide. New York: Sterling Publishing Co., Inc.

[5] Amadino, A., R. Susanti, dan R. Afriant. 2014 Gambaran Pola Dermatoglifi pada Ujung Jari Tangan Penderita Penyakit Hipertensi Esensial di Kota Padang Tahun 2014. Jurnal KesehatanAndalas, 3(1):100-103.

[6] Dias, S. M., P. L. Martis, dan BhavyashreeRai. 2018. Determination of Hand of Origin of Fingerprints by Analysing Fingerprint Characteristics of Whorl Patterns. Journal of Forensik Science and Criminal Investigation, 9(3): 1-12.

[7] Gottimukkula, D. R, R. K. Chakinala, S. Kagithapu, Y. Morishetty, dan G. Puchchakayala. 2017. Down's Syndrome-Case Series. SM. Journal of Case Reports, 3(1): 1-3.

[8] Grieco, J., M. Pulsifer., K. Seligsohn., B. Skotko, dan A. Schwartz. 2015. Down Syndrome: Cognitive and Behavioral Functioning Across the Lifespan. 
American Journal of Medical Genetics Part C, 16C: 135-149.

[9] Irawan, R. B., L. Rujito, M. Ferine, dan Z. S. Hidayat. 2010. Perbedaan Pola Sidik Jari Anak-anak Sindrom Down dan Anak-anak Normal di Purwokerto. $J$. Medical UnSoed, 2(2): 106 -116.

[10] Jenkins, J.B. 1990. Human Genetics. New York: Harper Collins Publishers, Inc.

[11] Kanbar, A. B. 2016. Fingerprint Identification for Forensic Crime Scene Investigation. International Journal of Computer Science and Mobil Computing, 5(8): 60-65.

[12] Kazemi, M., M. Salehi., M. Kheirollahi. 2016. Down Syndrome: Current Status, Challenges and Future Perspectives. Int J Mol Cell Med, 5(3): 125-133.

[13] Kosim, M. S., A. Yunanto, R. Dewi, G. I. Sarosa, dan A. Usman. 2012. Buku Ajar Neonatologi. Jakarta: Badan Penerbit IDAI.

[14] Laksono, S. P., Qomariyah, dan E. Purwaningsih. 2011. Persentase Distribusi Penyakit Genetik dan Penyakit yang dapat Disebabkan Oleh Faktor Genetik di RSUD Serang. Majalah Kesehatan Pharma Medika, 3(2): 267-271.

[15] Mridula, P. 2014. A Review on Classification of Fingerprint Images. IOSR Journal of Electronics and Communication Engineering, 9(3): 61-66.

[16] Mundijo, T. 2017. Gambaran Pola Sidik Jari dan Sudut Axial triradius Digital (ATD) pada Anak Sekolah Dasar Negeri 144, Talang Betutu, Palembang, Sumatera Selatan. Syifa' MEDIKA, 7(2): 99-103.

[17] Myrelid, A., J. Gustafsson, B. Ollars, dan G. Anneren. 2002. Growth Charts for Down's Syndrome from Birth to 18 Years of Age. Arch Dis Child, 87: 97-103.

[18] Nurwahidah, S., W. Soewondo, dan I. S. Sasmita. 2015 Prevalensi Sindroma down di Wilayah Priangan pada Tahun 2015. Jurnal Kedokteran Gigi Unpad, 29(3): 189-195.

[19] Oliver, T. R., E. Feingold, K. Yu, V. Cheung, S. Tinker, M. Yadav-Shah, N. Masse, dan S. L. Sherman. 2008. New Insights into Human Nondisjunction of Chromosome 21 in Oocytes. PloS Genetics, 4(3): 1-9.

[20] Purbasari, K., dan A. R. Sumadji. 2017. Variasi Pola Sidik Jari Mahasiswa Berbagai Suku Bangsa di Kota Madiun. Jurnal Florea, 4(2): 47-54.

[21] Rahma, M. S., dan E. S. Indrawati. 2017. Pengalaman Pengasuhan Anak Down Syndrome. Jurnal Empati, 7(3): 223-232.

[22] Ramani, P., Abhilash, H. J. Sherlin, Anuja, P. Premkumar, Chandrasekar, G. Sentamilselvi, V. R. Janaki. 2011. Conventional Dermatoglyphics. International Journal of Pharma and Bio Sciences, 2(3): 446-458.

[23] Rosida, L., dan R. Panghiyangani. 2006. Gambaran Dermatoglifi pada Penderita Sindrom Down di Banjarmasin dan Martapura Kalimantan Selatan. Jurnal Anatomi Indonesia, 1(2): 71-78.

[24] Sanilkumar, M. N. 2014. The Enigma of the Simian Crease: Case Series with the Literatur Review. Internasional Journal of Contemporary Pediatrics, 1(3): $175-177$.
[25] Saraydemir, S., N. Taspinar, O. Erogul, H. Kayserili, dan N. Dinckan. 2012. Down Syndrome Diagnosis Based on Gabor Wavelet Transform. J. Med Syst, 36: 3205-3213.

[26] Siburian, J., E. Anggreini, dan S. F. Hayati. 2010. Analisis Pola Sidik Jari Tangan dan Jumlah Sulur serta Besar Sudut ATD Penderita Diabetes Mellitus di Rumah Sakit Umum Daerah Jambi. Biospecies, 2(2): 12-17.

[27] Sufitni. 2007. Pola Sidik Jari Pada Kelompok Retardasi Mental dan Kelompok Normal. Majalah Kedokteran Nusantara. 40 (3):180-191.

[28] Sureshbabu, R., R. Kumari, S.Ranugha, R. Sathyamoorthy, C. Udayashankar, dan P. Oudeacoumar. 2011. Phenotypic and Dermatological Manifestations in Down Syndrome. Dermatology Online Journal.

[29] Suryo. 2016. Genetika Manusia. Yogyakarta: Gadjah Mada University Press.

[30] Thomas, R., dan D. Harvey. 1992. Atlas Bantu Neonatologi. Jakarta: Hipokrates.

[31] Wati, M., R. R. P. Megahati, dan F. Hayuni. 2016. Pengamatan Pola Sulur Jari dan Telapak Tangan pada Anak Penyandang ADHD (Attention Deficit Hyperactivity Disorder) di Kota Padang. BioCONCETTA, 2(1): 43-49. 